\title{
RESISTANCE Escherichia coli ISOLATES TO ANTIBIOTICS FROM THE ORGAN SAMPLES ORIGINATING FROM SWINE FARMS
}

\author{
R. Došen, J. Prodanov-Radulović, I. Pušić, I. Stojanov, D. Stojanović, R. \\ Ratajac
}

Scientific Veterinary Institute "Novi Sad", Rumenački put 20, 21000 Novi Sad, Republic of Serbia Corresponding author: jasna@niv.ns.ac.yu

Orginal scientific paper

Abstract: Bacteria Escherichia coli (E.coli) is a ubiquitous microorganism with a different serotypes, that cause septicemia in neonatal piglets, diarrhea in suckling piglets, diarrhea and edemic disease in weaned piglets. Vaccination and antibiotic treatment are less effective ways in solving the problem, especially when the category of pig is not taken into consideration, as well as feed safety and chemical composition of feed. The resistance of pathogens depends on the farm size, production type and pigs category raised on the farm. In addition, the antibiotics used for veterinary purposes reduce their effectiveness in human medicine. Analyzing the antibiograms results obtained from the isolates of dead piglets with $E$. coli infection in last two years (2007-2009), it can be concluded that $E$. coli strains developed resistance to most chemotherapeutics. Applying bacteriological examination it was detected that the isolates of E. coli are highly sensitive to the following chemotherapeutics: Floron (86.36\%), Cobactam $(71 \%)$, Enrofloxacin (54.84\%), Neomycin (38.71\%), Gentamicin (38.71\%), Lincospectin (29\%), Flumequine (29\%), Amoxicillin (26.66\%), Colistin (17.39\%), Penicillin (9.67\%), Tiamulin (6.45\%), Tetracycline (6.45\%), Doxycycline $(6.45 \%)$, Streptomycin $(3.22 \%)$. Intermediate degree of sensitivity was found with: Flumequin (38.71\%), Colistin (34.78\%), Cobactam (30\%), Tilozin $(29.17 \%)$, Gentamicin (25\%). E. coli strains were the least resistant to Cobactam (not detected), Floron (4.54\%), Neomycin (12.9\%), Colistin (13.04\%), Flumequin $(19.35 \%)$.

Key words: antibiotcs resistance, Escherichia coli, pigs

\section{Introduction}

Diarrhea in sucking and postweaning piglets causes economic losses due to mortality, morbidity, reduced daily gain, increased conversion and costs caused by 
treating sick piglets. It is usually caused by Escherichia coli infection bearing f4 (K88) or f18 adhesin. There are two related antigenic variants of f18, f18ab and f18ac. Edema disease is caused by the strains that have f 18 and f18ac associated with diarrhea (Debroy et al., 2009).

Lately, an increse in incidence of outbreaks of severe E. coli-associated diarrhea have been observed worldwide. The factors contributing to the increased number of outbreaks are not fully understood. The reason may be more virulent strains of E. coli clones, such as O149: LT: STA: STB: EAST1: f4ac, or recent changes in the management of pigs (Fairbrother et al 2005). The extensive use of antibiotics in bacterial infections in human and veterinary medicine select for resistant microorganism which may, in turn, transfer resistance factor to other bacteria thereby further enhancing their spread (Levy, 1984; Levy, 1988). Many authors have tried to link the use of antibiotics in animal feed with increased risk of pathogen resistance (Stobberingh et al., 1999; White et al., 2001). Because of the intensive use of antimicrobial agents in the production of feed, meat is frequently contaminated with resistant strains of $E$. coli. Humans can become infected by $E$. coli of animal origin, and because of resistance to commonly used antimicrobial agents, these bacteria may cause infections for which limited therapeutic options are available. Bacteria from the animal reservoir that carry resistance to antimicrobial agents that are regarded as highly or critically important in human therapy (aminoglycosides, fluoroquinolones, third- and fourth- generation cephalosporins) are of especially great concern (Hammerum et al., 2009). On the basis of the EC Directive No 99/2003 many European countries have implemented monitoring of antimicrobial resistance to bacteria (Stannarius et al., 2009). Unfortunately, the control of antibiotic and chemotherapeutic use in veterinary medicine has not been established in the Republic of Serbia (Gavrović et al., 2011).

Due to antimicrobial resistance in the industrial-type of swine farms in Serbia antibiotics are used in prophylaxis, metaphylaxis and therapy (through food and water) in very high doses. This strategy resulted in expansion (multiplication) of highly resistant strains. The aim of this study is to discuss the problem of bacterial resistance and highlight the need to implement new strategies in the control of bacterial infections.

\section{Materials and Methods}

As material for study, we used parts of parenchymatous organs (kidney, liver, mesenterial lymph nodes and lungs) from pigs that died with clinical signs (diarrhea, signs of edema disease) and pathomorphological signs of infection (hemorrhagic gastroenteritis, gastric mucosal edema and mesocolon). The pigs come from different industrial type of farms (over 2000 sows, where antibiotics are used continuously in the prophylaxis of E. coli and other infections). Antibiotics 
are used in the prophylaxis, but more frequently they are administred in therapeutic doses. Isolation of $E$. coli was performed using nutrient and selective media. The material was streaked directly, by a loop, and inoculated on blood and MacConkey agar. After incubation for $24-48$ hours at $37^{\circ} \mathrm{C}$, Gram and oxidase negative, lactose positive micro-organisms with fermentative properties were detected by determining the physiological features. Determining sensitivity to antibiotics was carried out by the disk diffusion method in relation to particular chemoterapeutic group (aminoglycosides, flor-chinolones, tetracyclines, synthetic penicillins, sulphonated products, lincozamine). Antibiograms were made on Mueller-Hinton media and the suspension was steaked at density of $0.5 \mathrm{McF}$ arland. The suspension was smeared with a sterile swab over the entire surface and incubated for 24 hours at $37^{\circ} \mathrm{C}$. Determination of the sensitivity of isolates to antibiotics was performed according to manufacturer's instructions, that give a recommendation for the zone of inhibition, expressed in millimeters, which appear around the antibiotic discs, and characterize the sensitivity, i.e. the resistance of the strains.

\section{Results and Discussion}

The results obtained in last two years (2007-2009) were analysed. From the organs of dead pigs showing the signs of $E$. coli infection, the appearance of resistance of $E$. coli strains to a number of chemotherapeutics was determined. Bacteriology examination showed that $E$. coli isolates were highly sensitive to these chemotherapeutics: floron $(86.36 \%)$, cobactam $(71 \%)$, enrofloxacin (54.84\%), neomycin (38.71\%), gentamycin (38.71\%), linkospektin (29\%), flumekvin (29\%), amoxicillin $(26.66 \%)$, colistin $(17.39 \%)$, penicillin $(9.67 \%)$, tiamulin $(6.45 \%)$, tetracycline $(6.45 \%)$, doksicilin $(6.45 \%)$, streptomycin $(3.22 \%)$. Mid-level of sensitivity was established in flumekvin (38.71\%), colistin (34.78\%), cobactam $(30 \%)$, tilozin $(29.17 \%)$, gentamycin $(25 \%)$. E. coli strains were the least-resistant to cobactam (not established), floron (4.54\%), neomycin (12.9\%), colistin (13.04\%), flumekvin (19.35\%). The resistance to antibiotics was also established in the strains isolated from healthy pigs. A large number of resistant strains was established on the farms where antibiotics have not been used as growth promoters or in the prophylaxis, so what suggests that antibiotics are not the only selective factors for antibiotic resistance (Chikwendu et al., 2008). The antibiotic resistant microflora that developed from the use of antibiotics prior to 1972 has been passed on from one generation to the next, even though anbitiotics have not been used for any purpose (Langlois et al., 1986).

E. coli strain resistance to investigated antimicrobial agents was significantly different depending on the species age and health status of the animals. The majority of isolated E. coli strains examined for antibiotics and chemotherapeutics showed a resistance to 15 , and sensitivity only to 
cephalosporines of the III generation and colistin (Krnjaić et al., 2005). The researchers in Danish pig slaughterhouses found no statistically significant influence of regional, seasonal and temporal variations. In addition, they found that the winter months were associated with an increased risk for the occurence of resistant E. coli as compared to other periods of the year (Abatih et al., 2009). The analysis of the samples from different farms showed that $E$. coli strains differ in sensitivity from farm to farm. In general, the $E$. coli strains were most sensitive to colistin and enrofloxacin, less sensitive to flumkvin and oldoxin, but almost totaly or partially resistant to all other antibiotics. On the farm $\mathrm{C}$ a strain resistant to all antibiotics was detected, while on the farm $\mathrm{D}$, a strain sensitive only to floron and streptomycin, but resistant to all other antibiotics was isolated (Table 1).

Table 1. Antibiogram for $E$. coli according to the farms (piglets in nursery)

\begin{tabular}{|l|c|c|c|c|c|c|c|c|c|c|c|c|c|c|c|c|}
\hline & \multicolumn{2}{|c|}{$\mathrm{A}$} & $\mathrm{B}$ & $\mathrm{C}$ & $\mathrm{D}$ & \multicolumn{3}{l|}{$\mathrm{G}$} & \multicolumn{3}{|c|}{$\mathrm{H}$} & $\mathrm{I}$ & $\mathrm{J}$ & $\mathrm{K}$ & $\mathrm{L}$ \\
\hline & 1 & 2 & 3 & 4 & 5 & 6 & 7 & 8 & 9 & 10 & 11 & 12 & 13 & 14 \\
\hline enrofloksacin & 2 & 3 & 2 & 0 & 0 & 0 & 3 & 3 & 2 & 2 & 2 & 3 & 0 & 3 \\
\hline Floron & 2 & 2 & - & - & 2 & 2 & 2 & 3 & - & 0 & 0 & - & 2 & 3 \\
\hline colistin & - & 3 & - & - & - & 0 & 0 & 3 & 2 & 2 & 3 & - & 2 & 3 \\
\hline Oldoxin & 0 & 3 & 0 & 0 & 0 & 2 & 3 & 3 & 0 & 0 & 2 & 3 & 2 & 2 \\
\hline amoksicilin & 2 & 0 & 2 & 0 & - & 0 & 0 & 3 & 2 & 2 & 0 & 0 & 0 & 0 \\
\hline flumekvin & 0 & 0 & 2 & 0 & 0 & 0 & 3 & 3 & 0 & 2 & 0 & 0 & 0 & - \\
\hline streptomycin & 2 & - & 2 & 0 & 2 & 2 & 0 & 0 & 0 & 0 & - & 0 & 2 & 0 \\
\hline dokxicol & - & 2 & - & - & 0 & 0 & 0 & - & 0 & 3 & 2 & - & - & 0 \\
\hline gentamycin & 0 & 3 & 0 & 0 & 0 & - & 0 & 0 & 0 & 0 & 0 & 0 & 2 & 0 \\
\hline penicillin & 0 & 0 & 0 & 0 & 0 & 0 & 0 & 0 & 2 & 0 & - & 0 & 0 & 0 \\
\hline neomycin & 0 & 0 & 2 & 0 & 0 & 0 & 0 & 0 & 0 & 0 & 0 & 0 & 0 & 0 \\
\hline ampitrex & 2 & - & - & 0 & 0 & - & - & - & 2 & 2 & - & - & 0 & - \\
\hline poltesan & - & - & 0 & 0 & - & - & - & - & 0 & - & - & 2 & - & - \\
\hline tiamulin & 0 & 0 & 0 & 0 & 0 & 0 & 0 & 0 & 0 & 0 & 0 & 0 & 2 & 0 \\
\hline tilozin & 0 & 0 & 0 & 0 & 0 & 0 & 0 & 0 & 0 & 0 & 0 & 0 & 0 & 0 \\
\hline lincospekt. & 2 & 0 & 2 & 0 & 0 & 0 & 0 & 2 & 0 & 0 & 0 & 0 & 2 & 2 \\
\hline tetraciclin & 0 & 0 & 0 & 0 & 0 & 0 & 0 & 0 & 0 & 0 & 0 & 0 & 2 & 0 \\
\hline doksivet & - & 0 & - & - & - & 0 & 0 & 0 & - & 0 & 0 & - & 2 & 0 \\
\hline
\end{tabular}

E. coli strains sampled from the pigs in the farrowing pens were less resistant than the samples taken from piglets in nursery. The samples in both groups showed a higher level of sensitivity to neomycin, enrofloxacin and cobactam (2 to 3$)$. The study has detected strains highly resistante to all antibiotics. The sample No. 3 was resistant to all antibiotics, except little sensitivity to nemycin, tilosin i cobactam. The sample No. 4 was resistant to all antibiotics, but showed little sensitivity to nemycin, flumekvin, enrofloxacin, cobactam. In one study in Switzerland a susceptibility testing was performed on 429 isolates from weaned pigs and 431 isolates from sows. Overall, $17.7 \%$ of the isolates from weaned pigs and $22.5 \%$ of the E. coli isolates from sows were susceptible to all antibiotics tested. (Stannarius et al., 2009). 


\title{
Conclusion
}

In the past two years (2007-2009) the antibiograms, on the isolates from dead pigs with the signs of $E$. coli infection, were analyzed and the development of resistance of $E$. coli strains to a number of chemotherapeutics was determined. The occurance of strains resistant to a wide range of antibiotics, as well as greater incidence and severity of diarrhea in piglets after weaning, demands the use of alternative measures for their control. A new strategy involves vaccination with live oral vaccine, containing avirulent $E$. coli strains bearing adhesin fimbirial or oral administration of purified f4 (K88) fimbria. Sofar, no strategy has not proved to be completely safe and probably the most effective approach is a combination of modified dietary measures and other preventive measures.

\section{Acknowledegment}

Research was financed by the Ministry of Education and Science, Republic of Serbia, project TR 031071.

\section{Antibiotska rezistencija izolata Escherichia coli iz uzoraka organa sa farmi svinja}

\author{
R. Došen, J. Prodanov-Radulović, I. Pušić, I. Stojanov, D. Stojanović, R. Ratajac
}

\section{Rezime}

Rezistencija Escherichia coli je vezana za veličinu farme, tip proizvodnje i kategoriju svinja na farmi. Pored toga, upotreba antibiotika u veterinarskoj medicini limitira njihovu efikasnost u humanoj medicini. Analizom rezultata antibiograma dobijenih na izolatima u protekle dve godine (period 2007-2009) iz organa uginule prasadi sa znacima koli-infekcije, utvrđen je razvoj rezistencije sojeva $E$. coli na veliki broj hemoterapeutika. Bakteriološkim ispitivanjem je ustanovljeno da su izolati $E$. coli veoma osetljivi na sledeće hemoterapeutike: floron, kobaktam, enrofloksacin, neomicin, gentamicin, linkospektin, flumekvin, amoksicilin, kolistin, penicilin, tiamulin, tetraciklin, doksicilin, streptomicin. Srednji stepen osetljivosti uzročnika je ustanovljen na: flumekvin, kolistin, kobaktam, tilozin, gentamicin. Najmanje rezistentnih sojeva $E$. coli je bilo na kobactam (nije ustanovljena), floron, neomicin, kolistin, flumekvin.

\section{References}

ABATIH E.N., EMBORG H.D., JENSEN V.F., WONG D.M., ERSBØLL A.K. (2009): Regional, seasonal, and temporal variations in the prevalence of 
antimicrobial-resistant Escherichia coli isolated from pigs at slaughter in Denmark (1997-2005). Foodborne Pathog Dis., 6, 3, 305-319.

CHIKWENDU C.I., NWABUEZE R.N., ANYANWU B.N. (2008): Antibiotic resistance profile of Escherichia coli from clinically healthy pigs and their commercial farm environments. African Journal of Microbiology Research, 2, 012-017.

DEBROY C., ROBERTS E., SCHEUCHENZUBER W., KARIYAWASAM S., JAYARAO B.M. (2009): Comparison of genotypes of Escherichia coli strains carrying F18ab and F18ac fimbriae from pigs. J Vet Diagn Invest., 21, 3, 359-364.

FAIRBROTHER J.M, NADEAU E., GYLES C.L. (2005): Escherichia coli in postweaning diarrhea in pigs: an update on bacterial types. Anim Health Res Rev., 6, 1, 17-39.

GAVROVIĆ M., AŠANIN R., MIŠIĆ D., JEZDIMIROVIĆ M., ŽUTIĆ M. (2011): Investigation of the sensitivity of $E$. coli strains isolated from domestic animals to antibiotics and hemiotherapeutics in vitro Acta Veterinaria, 61, 1, 21-31. HAMMERUM AM, HEUER OE (2009): Human health hazards from antimicrobial - rezistant Escherichia coli of animal origin. Clin Infect Dis., 48, 7, 916-921.

KRNJAIĆ D., MIŠIĆ D., AŠANIN R. (2005): Investigation of sensitivity and resistance to antibiotics and chemotherapeutics in $E$. coli strains isolated from animals bred in intensive farming conditions. Acta Veterinaria (Beograd), 55, 5-6, 501-509.

LANGLOIS B., DAWSON K., CROMWELL G., STAHLY T. (1986): Antibiotc resistance in pigs following a 13 year ban. J. Anim. Sci., 62, 3, 18-32.

LEVY S. B. (1984): Playing antibiotic pool: time to tally the score. New England Journal of Medicine, 311, 663-665.

LEVY S.B., MARSHALL B., SCHLUEDERBERG S., ROWSE D., DAVIES, J. (1988). High frequency of antimicrobial resistance in human fecal flora. Antimicrobial Agents and Chemotherapy, 32,1801-1806.

STANNARIUS C., BÜRGI E., REGULA G., ZYCHOWSKA M.A., ZWEIFEL C., STEPHAN R. (2009): Antimicrobial resistance in Escherichia coli strains isolated from Swiss weaned pigs and sows, Schweiz Arch Tierheilkd., 151, 3, 119-125.

STOBBERINGH E., VAN DEN BOGAARD A., LONDON N., DRIESSEN C., J. TOP, WILLEMS R. (1999): Enterococci with glycopeptide resistance in turkeys, turkey farmers, turkey slaughterers, and (sub)urban residents in the south of The Netherlands: evidence for transmission of vancomycin resistance from animals to humans? Antimicrob. Agents Chemother., 43, 2215-2221.

WHITE D.G., ZHAO S., SUDLER R., AVERS S., FRIEDMAN S., CHEN S., MCDERMOTT P., MCDERMOTT S., WAGNER D.D., MENG J. (2001): The isolation of antibiotic-resistant Salmonella from retail ground meats. N. Engl. J. Med., 345,1147-1154. 